\title{
Lokasi Pusat Kadipaten Tuban Berdasarkan Informasi dari Serat Babad Thuban
}

\author{
Teguh Fatchur Rozi ${ }^{1} \mid$ Ageng Gumelar Wicaksono ${ }^{2}$
}

${ }^{1}$ Pascasarjana Kajian Islam UIN Sayyid Ali Rahmatullah Tulungagung

${ }^{2}$ Teknik Mesin

Politeknik Negeri Malang

Correspondence:

Teguh Fatchur Rozi

Pascasarjana Kajian Islam UIN Sayyid Ali Rahmatullah Tulungagung

tegoeh950@gmail.com

\section{Article History:}

Received 21 September 2021

Revised 16 November 2021

Accepted 30 November 2021

\begin{abstract}
Serat Babad Thuban was a literary work composed by a poet who didn't want to publish his identity. It has become the main reference for historians to look for the names of the Adipatis of Tuban who had been the ruler and the seat of the government or administrative centre of Kadipaten of Tuban. The aim of this study was to describe the locations of the seat of the goverment of the Kadipaten of Tuban as recorded in the 3rd printed version of the Serat Babad Thuban by Boekhandel Tan Khoen Swi. The method used in this study was literature study, studies relating to library data collection, reading and taking notes, and managing research materials in the study reference, namely the printed version of Serat Babad Thuban.The result of this study was: Kadipaten of Tuban had seven times moved its administrative centre. The first was in Papringan, it was located to the west of Gabar Cave, then its relocated to Sidamukti Village, Dagan Village, Kahibon Village, Prunggahan Village, and Gowah Village.

Keywords: Serat Babad Thuban, Kadipaten of Tuban, Administrative Centre
\end{abstract}

\begin{abstract}
Abstrak
Serat Babad Thuban merupakan sebuah karya sastra yang digubah oleh seorang pujangga yang tidak berkenan memublikasikan identitasnya. Serat tersebut menjadi rujukan utama sejarawan untuk mencari nama-nama Adipati Tuban yang pernah berkuasa beserta pusat pemerintahannya. Kajian ini bertujuan untuk memaparkan lokasi-lokasi pusat pemerintahan Kadipaten Tuban sebagaimana yang telah tercatat dalam Serat Babad Thuban versi cetakan ke-3 oleh Boekhandel Tan Khoen Swi. Penelitian menggunakan metode studi kepustakaan atau studi literatur, kajian yang berkenaan dengan pengumpulan data pustaka, membaca dan mencatat, serta mengelola bahan penelitian dalam rujukan kajian, yakni Serat Babad Thuban versi cetak. Hasil dari kajian ini yaitu: Kadipaten Tuban telah mengalami tujuh kali pemindahan pusat kadipaten. Yang pertama kali berada di Papringan, sebelah barat Gua Gabar, kemudian ke Kampung Sidamukti, Kampung Dagan, Kampung Kahibon, Dusun Prunggahan, dan Kampung Gowah.

Kata Kunci: Serat Babad Thuban, Kadipaten Tuban, Pusat Pemerintahan
\end{abstract}




\section{Pendahuluan}

Tuban merupakan salah satu kota tua yang berada di pesisir utara Pulau Jawa bagian timur. Luas wilayah Kabupaten Tuban saat ini adalah \pm 183.994.561 Ha, dengan dilengkapi wilayah laut seluas $\pm 22.068 \mathrm{~km}^{2}$. Posisi Tuban sekarang berada

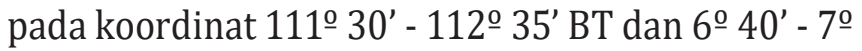
18 ' LS. Panjang wilayah pantainya $\pm 65 \mathrm{~km}$. Secara administratif, Kabupaten Tuban termasuk dalam wilayah Provinsi Jawa Timur. Secara geografis, posisi Kabupaten Tuban berbatasan dengan Laut Jawa di bagian utara, Kabupaten Lamongan di bagian timur, Kabupaten Bojonegoro di bagian selatan dan Kabupaten Rembang di bagian barat (Tim Penyusun, 2015).

Sejarah panjang sudah terjadi di Tuban. Bukti tertulis paling tua di Tuban berasal dari abad ke-11 Masehi, yakni pada era Kerajaan Janggala (Prihatmoko, 2011; Susanti, 2010). ${ }^{1}$ Pada perjalanan waktu tersebut, puluhan Adipati sudah memimpin di Tuban, hal itu bisa dilihat di Serat Babad Thuban karya seorang pujangga yang tidak berkenan menyebut namanya (anonim, ed.). Serat Babad Thuban (1936) merupakan rujukan utama jika hendak mencari nama-nama pemimpin di Tuban. Jika dilihat dari isi babad tersebut, pemimpin terakhir yang disebut adalah Raden Tumenggung Prihanggawinata. Hal itu mengindisikan bahwa Babad ini ditulis pada awal abad ke-20 Masehi, karena Raden Tumenggung Prihanggawinata menjadi pemimpin di Tuban pada tahun 1911-1919 (Patria, 2014; Swie, 1936).

Hingga saat ini Serat Babad Thuban hanya diketahui versi cetakannya saja. Sedangkan versi asli tulisan tangan belum diketahui. Serat Babad Thuban telah dicetak oleh penerbit Boekhandel Tan Khoen Swie dengan memakai aksara Jawa pada tahun 1936 di Kediri. Babad ini disebar dan diperjualbelikan oleh penerbit dengan harga f. 0,45 (Swie, 1936). Selain menyebut nama-nama Adipati di Tuban, babad ini juga menyebut lokasi ibukota adipati saat itu menjabat. Serat Babad Thuban telah menjelaskan bahwa pusat kadipaten Tuban sendiri mengalami perpindahan beberapa kali. Sekitar ada tujuh pusat kadipaten yang pernah ditempati oleh Adipati-Adipati di Tuban (Prihatmoko, 2011). Suatu hal menarik dan hingga saat ini penulis belum pernah menjumpai suatu kajian yang fokus melakukan identifikasi lokasi-lokasi pusat Kadipaten Tuban pada masa lampau. Oleh sebab itu, kajian ini bertujuan untuk mencari lokasilokasi pusat pemerintahan Kadipaten Tuban yang sebagaimana ditulis di Serat Babad Thuban dan berusaha mencari lokasi administrasi saat ini.

\section{Metode Penelitian}

Sesuai dengan permasalahan yang menjadi fokus kajian, maka penelitian ini dikategorikan dalam jenis penelitian studi literatur. Penelitian studi literatur merupakan serangkaian kegiatan yang berkenaan denganmetodepengumpulandatapustaka,membaca dan mencatat, serta mengelolah bahan penelitian (Zed, 2014). Studi literatur merupakan kegiatan yang diwajibkan dalam penelitian, khususnya penelitian akademik yang tujuan utamanya adalah mengembangkan aspek teoritis maupun aspek manfaat praktis. Studi literatur dilakukan oleh setiap penulis dengan tujuan utama yaitu mencari dasar pijakan/fondasi untuk memperoleh dan membangun landasan teori, kerangka berpikir, dan menentukan dugaan sementara atau disebut juga dengan hipotesis penelitian. Sehingga penulis dapat mengelompokkan, mengalokasikan mengorganisasikan, dan menggunakan variasi pustaka dalam bidangnya. Dengan melakukan studi literatur, penulis mempunyai pendalaman yang lebih luas dan mendalam terhadap masalah yang hendak diteliti (Darmadi, 2011).

Data yang diperoleh pada penelitian ini berasal dari Serat Babad Thuban. Dalam kaitan ini peneliti 
membaca Serat Babad Thuban versi cetakan keIII yang diterbitkan oleh penerbit Boekhandel Tan Khoen Swi pada tahun 1936 di Kediri. Sebenarnya peneliti hendak mencari langsung versi asli tulis tangannya, namun hingga saat ini peneliti belum pernah menjumpainya. Walaupun Babad ini dalam versi cetakan, namun penerbit tetap menulisnya memakai aksara Jawa.

\section{Hasil dan Pembahasan}

Tuban telah melalui sejarah panjang dalam dinamika perjalanannya. Berdasarkan peninggalanpeninggalan masa lalu yang masih tersisa, pusatpusat perkembangannya meliputi Desa Kutorejo dan Desa Sendangharjo yang masih terdapat sisa-sisa pusat kegiatan politik dan administrasi di sekitar alun-alun, pusat komersial di sekitar Kajongan dan Pasar serta Boom (Sedyawati, et al., 1997). Namun jika membaca penjelasan dalam Serat Babad Thuban disebutkan bahwa pusat Kadipaten Tuban telah mengalami beberapa kali pemindahan.

Berdasarkan isi dari Serat Babad Thuban pusat kadipaten Tuban pertama berada di Alas Papringan. Hal itu telah dijelaskan di Serat Babad Thuban:

IV .... pŕamila sary hinkay rama séda Radén Harya Dhaṇdanwacaṇa lajěy hutusșan wadya pungawa-nnipun babad hin wana Paprírinan [bokmanawi hiך wěkdal punika wahu wana kațah:

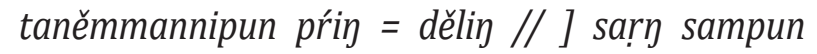
dados nagari kaparinnan nami: Thuḅan / ... (Swie, 1936).

... maka ketika sang ayah mangkat Raden Harya Dhandangwacana lalu mengutus prajurit punggawanya membuka hutan Papringan [barangkali pada waktu itu tadi hutan banyak: tanaman bambu = buluh// ] ketika telah menjadi negeri diberi nama: Thuban / ...

Raden Arya Dandang Wacana merupakan Adipati Tuban pertama. Ia adalah anak dari Raden
Arya Dandang Miring yang merupakan seorang pemimpin di Lumajang. Sebelum mangkat, Raden Arya Dandang Miring berpesan kepada Raden Arya Dandang Wacana supaya ia menjalankan pesan dari dewata yang dia dapat ketika bertapa. Selepas Raden Arya Dandang Miring mangkat nanti, Raden Arya Dandang Wacana meninggalkan Lumajang dan mencari suatu tempat yang banyak pohon bambu. Di sanalah Raden Arya Dandang Wacana bertempat tinggal dan memimpin wilayah tersebut (Tim Penyusun, 1987).

Tidak berjarak jauh dari Lumajang, tempat yang diarahkan oleh ayahnya mengarah ke alas Papringan. Di alas Papringan Raden Arya Dandang Wacana dan pengikutnya membuka hutan untuk dijadikan tempat tinggal. Pada saat membuka hutan tersebut, tiba-tiba keluarlah air dari tanah. Ternyata di Alas Papringan ini dijumpai banyak sumber air, dan airnya sangat jernih. Karena peristiwa itu kemudian wilayah tersebut disebut Thuban. Hal itu berangkat dari perkataan spontan Raden Arya Dandang Wacana, "metu banyu". Setelah selesai membuka hutan Papringan, Raden Arya Dandang Wacana dinobatkan menjadi adipati di sana dan bergelar Kyahi Gedhe Papringan (Soeparmo, 1983). Hingga saat ini mayoritas masyarakat Tuban telah mempercayai Tuban berasal dari kata "metu banyu", kata tersebut merupakan pengucapan yang keluar ketika peristiwa membuka Alas Papringan ini.

Serat Babad Thuban (1936) juga menjelaskan di mana lokasi Alas Papringan tersebut. Hal itu telah dijelaskan di urutan nomer dua:

2. ... I| Praja Thuban higkan wiwittan wahu samajké dados 3 dhusun / a. Thŕawulan b. Pŕruygahhan Kulon c. Pŕruygahhan Wétan /... (Swie, 1936).

... Kerajaan Tuban yang tersebut pertama tadi sekarang menjadi 3 dusun / a. Trawulan b. Prunggahan Barat c. Prunggahan Timur / ... 
Pada awal abad ke-20, Alas Papringan masuk dalam administrasi di Desa Prunggahan dan dibagi menjadi tiga Dusun, yakni Dusun Trowulan, Prunggahan Kulon dan Prunggahan Wetan (Swie, 1936). Namun berjalannya waktu, Desa Prunggahan dipecah menjadi dua Desa, yakni Desa Prunggahan Kulon dan Prunggahan Kulon. Sedangkan Dusun Trowulan yang disebut dalam Serat Babad Thuban menjadi bagian dari Desa Bektiharjo, yang akan disebut pada pembahasan selanjutnya.

Setelah tiga tahun memimpin di Papringan, Raden Arya Dandang Wacana memerintah punggawanya untuk membuat pesanggrahan. Pesanggrahan ini dikelilingi parit dan kolam, sekelilingnya juga ditanami dengan aneka macam pohon. Pohonpohon itulah yang nantinya membuat pesanggrahan tersebut menjadi rindang dan membuat pemandangan lebih indah. Pesanggrahan tersebut saat ini diberi nama Bheti, kata tersebut berasal dari kata "Pangabekti" yang artinya pemujaan. Jika Raden Arya Dandang Wacana beristirahat di pesanggrahan tersebut, maka banyak punggawa kadipaten dan warga datang juga ke pesanggrahan untuk mangabhekti ke Raden Arya Dandang Wacana (Tim Penyusun, 2015). Sekarang nama desa yang menjadi lokasi dibangunnya pesanggrahan bernama Bektiharjo.

Raden Arya Dandang Wacana mempunyai dua anak, yaitu Nyahi Ageng Lanangjaya dan Nyahi Hageng Ngeso. Nyahi Hageng Lanangjaya berputra laki-laki satu bernama Raden Harya Ronggalawe dan Nyahi Hageng Ngeso juga mempunyai anak lakilaki satu bernama Raden Harya Kebonabrang. Raden Arya Dandang Wacana menjabat sebagai Adipati selama 30 tahun. Jabatan menjadi Adipati Tuban tersebut dilanjutkan oleh cucunya dari anak Nyahi Hageng Lanangjaya, yaitu Raden Harya Ronggalawe (Swie, 1936).

Serat Babad Thuban menjelaskan bahwa Raden Harya Ronggalawe telah memindahkan pusat pemerintahan Tuban di sebelah barat Gua Gabar:

2. ... || Radén Harya Rong.alawé sary juměněy Bupati Thuḅan dalm kabupatén kapiṇdạ wontěn hì sakilénnipun Guwa Gabar //... (Swie, 1936).

2. II Raden Harya Ranggalawe ketika naik takhta (menjadi) Bupati Tuban rumah kabupaten dipindah ke sebelah barat Guwa Gabar //

Setelah 30 tahun lamanya pusat Kadipaten Tuban berada di Papringan, kemudian pada masa Raden Harya Ronggalawe menjabat, ia memindahnya ke sebelah barat Gua Gabar. Serat Babad Thuban tidak menjelaskan apa alasan dari Raden Harya Ronggalawe memindahkannya ke sana, berbeda dengan pemindahan pusat Kadipaten yang dilakukan oleh pendahulunya. Raden Harya Rongg alawe menjabat sebagai Adipati Tuban selama 30 tahun.

Soeparmo (1983) berpendapat bahwa pusat pemerintahan Kadipaten Tuban yang digunakan pada masa Raden Harya Ronggalawe kala itu, saat ini menjadi area makam Bakung di Desa Karang, Kecamatan Semanding. Lokasi makam Bakung sendiri tidak jauh dengan Gua Gabar seperti yang diberitakan oleh penulis Serat Babad Thuban. Saat ini masyarakat Tuban menyebut Gua Gabar dengan nama Gua Akbar.

Pusat pemerintahan yang berada di sebelah barat Gua Gabar ini tidak hanya digunakan pada era Raden Harya Ronggalawe saja, namun dua Adipati penerusnya turut menggunakan lokasi tersebut. Dua Adipati tersebut bernama Raden Harya Siralawe yang menjabat selama 15 tahun dan Raden Harya Sirawenang yang menjabat selama 42 tahun. Jika dijumlah semuanya, pusat Kadipaten berada di Desa Karang ini digunakan 87 tahun lamanya.

Kemudian, pada masa pemerintahan Raden Harya Lena, pusat Kadipaten dipindah di Kampung Sidomukti:

5. ॥ Radén Harya Śrawěnaך puputrá Radén 
Harya Léna / sarn hinkay rama séda: Radén Harya Léña gěntosși juměněn ḅupati / laménnipun ṅantos 52 tahun hananiin da!m kabupatén lajěy kapiṇdạ

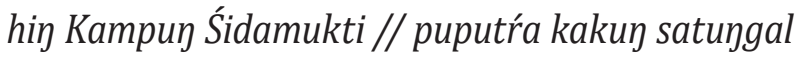
hasma Radén Harya Dikara // (Swie, 1936).

|| Raden Harya Sirawenang berputra Raden Harya Lena / ketika sang ayah mangkat: Raden Harya Lena menggantikannya (naik takhta) menjadi bupati / lamanya sampai 52 tahun namun rumah kabupaten kemudian dipindah ke Kampung Sidamukti // berputra lelaki satu bernama Raden Harya Dikara //

Raden Harya Lena merupakan anak dari Raden Harya Sirawenang, Adipati Tuban ke IV. Ia memindah pusat Kadipaten dari baratnya Gua Gabar menuju ke kampung Sidamukti. Sama halnya dengan sebelumnya, proses pemindahan pusat Kadipaten ini tidak diketahui, karena penulis Serat Babad Thuban tidak menjelaskannya secara lengkap.

Soeparmo (1983) berpendapat Kampung Sidomukti yang menjadi pusat pemerintahan Kadipaten Tuban pada masa Raden Harya Lena ini sekarang berubah nama menjadi Kelurahan Doromukti, Kecamatan Tuban. Jika dari pusat Kadipaten sebelumnya, Desa Karang, kelurahan Doromukti berada di utaranya. Serat Babad Thuban (1936) secara tidak langsung menjelaskan bahwa pusat pemerintahan di Kampung Sidomukti ini merupakan yang paling lama. Sekitar ada 12 Adipati yang bertempat di Kampung Sidomukti tersebut. Jika dijumlah semuanya, Kampung Sidomukti menjadi pusat Kadipaten ini digunakan 388 tahun lamanya.

Setelah lama berpusat di Kampung Sidamukti/ Doromukti, pada masa Pangeran Dalem pusat pemerintahan Tuban dipindah ke Kampung Dagan. Jika dilihat dari peta (Sedyawati et al., 1997), lokasi Kampung Dagan saat ini berada pada wilayah administrasi Kelurahan Kutorejo, Kecamatan
Tuban:

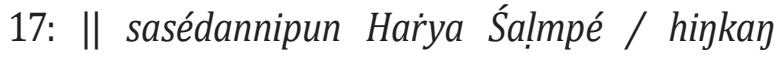
juměněy dados bupati / Panéran Daḷ / hiך

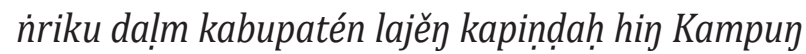
Dag.an sakidullipūn Watu Tiban / watawis tahun lajěn yasa Masjid Pagěr Banon sarta hiyasa bétén

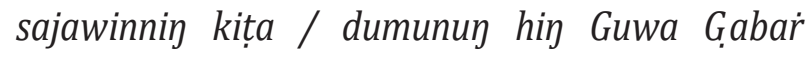
manétan tŕus manilén / (Swie, 1936).

|l sepeninggal Harya Salempe / yang naik tahta menjadi bupati / (adalah) Pangeran Dalem / saat itu rumah kabupaten dipindah ke Kampung Dagan di sisi selatan Watu Tiban / sementara tahun kemudian mendirikan Masjid Pager Banon serta membangun benteng (di bagian) luar kota / (yang) terletak di Guwa Gabar (membujur) dari timur lalu (ke) barat /

Penulis menduga bahwa pemindahan pusat kadipaten pada masa Pangeran Dalem ini sedikit banyak berkaitan dengan Kerajaan Mataram. Pada masa itu Tuban sedang berada di bayangbayang Kerajaan Mataram karena dengan tegas menolak untuk tunduk kepadanya. Adipati Tuban saat itu merasa Mataram merupakan penyebab persengketaan diantara Sultan Demak, Jipang, dan Pajang, yang sebelumnya berhubungan secara harmonis. Selain itu, Panembahan Senapati, Raja Mataram telah melakukan pemberontakan kepada Raja Pajang, yaitu Sultan Hadiwijaya (Ricklefs, 2011). Pangeran Dalem sendiri merupakan cucu dari Sultan Hadiwijaya dari jalur ibu.

Oleh karena itu, Tuban berusaha menentang pengaruh raja Mataram yang tidak memiliki hubungan apapun dengannya. Ketika itu Tuban juga telah menggabungkan diri dengan Surabaya sebagai aliansi kota wilayah pesisir Jawa. Panembahan Senapati dan penerusnya dengan misi ekspansinya mengincar wilayah-wilayah yang berada di bawah pengaruh Surabaya, yang ketika itu sedang tumbuh sebagai kota yang paling kuat di antara kota-kota 
pantai utara Pulau Jawa (Himmah, 2020; Nurhayati, 2017; Putra, 2019).

Usaha Pangeran Dalem untuk memberikan perlawanan kepada Mataram, kemungkinan besar disebabkan oleh kekhawatirannya jika pihak Mataram menyerbu Tuban di kemudian hari. Maka sebelum peristiwa tersebut menimpa di Tuban, Pangeran Dalem berupaya mempersiapkan segala hal untuk menghadapi pasukan Mataram. Strategi Pangeran Dalem diawali dengan membangun masjid dan benteng di luar kota, yang terletak di Gua Ghabar (Gua Akbar sekarang) membujur dari timur ke barat mengelilingi Kampung Dagan, pusat Kadipaten Tuban yang baru.

Pangeran Dalem mengutus Kyai Muhammad Asngari, seorang modin atau pemuka agama Majaghung untuk membangun benteng tersebut. Setelah benteng itu jadi, benteng tersebut diberi nama benteng Kumbakarna. Berita mengenai pembangunan benteng megah tersebut akhirnya diketahui oleh Raja Mataram yang saat itu dijabat oleh Sultan Agung. Berita tersebut membuat Sultan Agung murka. Kemudian Sultan Agung mengirim pasukan Mataram untuk menyerbu Tuban yang dipimpin oleh Pangeran Pojok (Tim Penyusun, 2015).

Pangeran Pojok memimpin invasi membawa sekitar 1.900 punggawa kerajaan ke Tuban. Setelah mengetahui bahwa Mataram akan menyerang, Pangeran Dalem menyiapkan pasukannya untuk menyambut serangan dari pasukan Mataram. Pertempuran besar-besaran akhirnya terjadi (de Graaf, 2001). Pada awalnya pertempuran tersebut dimenangkan oleh Tuban, namun kemudian Tuban dikepung sehingga menyebabkan pasukan Tuban kocar-kacir dan Pangeran Dalem melarikan diri ke pulau Bawean. Tidak berselang lama kemudian pergi ke Rajekwesi (Bojonegoro) hingga wafat.

Pangeran Pojok yang berhasil menginvasi Tuban, segera melapor kepada Sultan Agung bahwa Tuban telah kalah dan adipatinya melarikan diri. Pangeran Pojok kemudian didaulat menjadi penguasa Tuban.

Sejak itulah penguasa-penguasa Tuban merupakan utusan-utusan Sultan Mataram (STB, 1936). Setelah kekalahan Pangeran Dalem atas pasukan Mataram yang dipimpin oleh Pangeran Pojok, dan jabatan Adipati Tuban diganti olehnya, Serat Babad Thuban tidak memberitakan perpindahan pusat kadipaten. Walaupun de Graaf (2002) menjelaskan bahwa istana Tuban telah dihancurkan oleh pasukan Mataram.

Kemudian Serat Babad Thuban (1936) telah memberitakan bahwa Tuban pernah mengalami tanpa dipimpin seorang adipati. Setelah diberhentikannya Pangeran Anom dari jabatannya sebagai Adipati Tuban oleh Raja Mataram, Tuban mengalami kekosongan pemerintahan. Serat Babad Thuban tidak menceritakannya lebih rinci perihal alasan kenapa Pangeran Anom diberhentikan oleh Raja Mataram. Namun setelah peristiwa tersebut, struktur birokrasi di Tuban berubah menjadi sistem Wedana. Saat itu Tuban dibagi menjadi empat Wedana yang dijabat oleh Wangsa Praja di Jenu, Wangsa Hita di Gesik (Palang), Wangsa Cakra di Kidulngardi (Rengel) dan Yuda Patra di Singgahan:

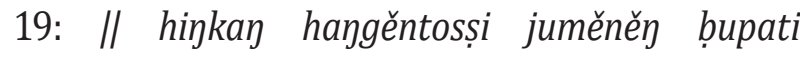
rayinnipūn Paniéran Pojok wasta: Pañéran Haṇom pikantuk 12 tahun lajěn kaléréḥhakěn șakin Matharam saléréhhipun Pañéran Haṇom lajěy kataněmman humbūl kémawon hì wěkdal

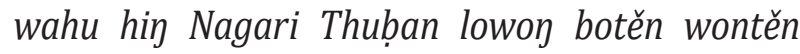
ḅupatinnipun wondé-ning humḅul wahu 4 pangénnan hingih punika:

1. // Woysa Pŕaja / mangén wontěn hị Jěṇu //

2. // Woysa Hita / mangén wontěn hiך Gěsik /

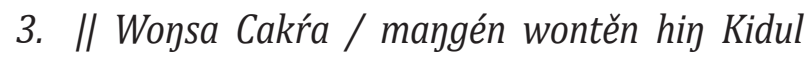
Nardi //

4. // Yuda Patŕa / mangén wontěn hiך Singaḥhan / (STB, 1936) 
|| yang menggantikan menjadi bupati (ialah) adiknya Pangeran Pojok bernama: Pangeran Hanom memerintah (selama) 12 tahun lalu diberhentikan dari Mataram. Setelah pember-hentian Pangeran Hanom kemudian ditanamkan/ ditempatkan humbul (wadana dusun/ perwakilan) saja pada waktu tadi di (saat) Negeri Thuban kosong tidak ada bupatinya sedangkan humbul (wadana dusun/ perwakilan) tadi (ada) 4 orang/tempat yaitu:

1. IWongsa Praja/bertempat di Jenu//

2. II Wongsa Hita/bertempat di Gesik/

3. II Wongsa Cakra/bertempat di Kidulngardi//

4. II Yuda Patra/bertempat di Singgahan/

Namun perubahan struktur birokrasi tersebut tidak berjalan lama, sistem Wedana diganti lagi dengan Adipati baru utusan dari Mataram. Harya Balabar yang juga dikenal sebagai Harya Blender adalah utusan dari Mataram menjabat Adipati Tuban ke-20. Ia memindah pusat Kadipaten ke Kampung Kahibon, yang lokasinya berada di sebelah selatan makamnya Kyahi Kusen:

20: || botěn lami lajěn dipūn gěntosși ḅupati saking Matharam wasta: Harya Balabar / hingih Harya Blèndẹer / dalm kabupatén lajēn

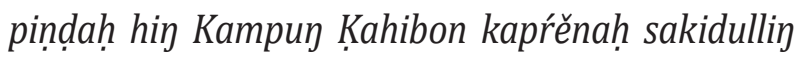
kuburrrannipun Kyahi Kusén haysal 39 tahun lajěn séda // (STB, 1936)

20: || tidak lama kemudian digantikan bupati dari Mataram bernama: Harya Balabar / juga (dikenal sebagai) Harya Blender / rumah kabupaten lalu pindah ke Kampung Kahibon (yang) terletak di sebelah selatan kuburannya Kyahi Kusen memerintah 39 tahun lalu mangkat//

Sedyawati, et al. (1997) mengidentifikasi lokasi Kampung Kaibon sekarang masuk dalam administrasi Kelurahan Kebonsari. Hal itu sangat bisa diterima karena Makam Kyahi Kusen sendiri masuk wilayah administrasi Kelurahan Kebonsari, yang mana Serat Babad Thuban (1936) telah memberitakan bahwa Kampung Kahibon ini berada di selatannya makam Kyahi Kusen. Lokasi pusat Kadipaten tersebut tidak jauh dengan lokasi pusat Kadipaten pada era Raden Harya Rangg.alawe yang berada di sebelah barat Gua Gabar, yang sekarang menjadi makam Bakung masuk di kelurahan Karang. Kelurahan Kebonsari dan Keluarahan Karang lokasinya bersebelahan namun berbeda kecamatan. Kelurahan Karang masuk di Kecamatan Semanding, sedangkan Kelurahan Kebonsari masuk di Kecamatan Tuban.

Harya Balabar menjabat menjadi Adipati Tuban selama 39 tahun, dan dalam kurun waktu itulah pusat Kadipaten Tuban berada di Kampung Kahibon. Kemudian Harya Balabar diganti oleh Pangeran Sujanapura sebagai Adipati Tuban ke-21. Pangeran Sujanapura merupakan Adipati Japan yang kemudian dipindah tugasnya menjadi Adipati Tuban:

21: || sasédannipun Harya Balabari: lajěy dipun gèntosși dhatěng Panéran Śujanapūra / Ḅupati Japan [Majakèrta] dalm kabupatén lajěy piṇdah hig Dhusun Pŕuggaḥhan Panéran Śujanapura juměněn ḅupati laménnipūn 10 tahun lajěn séda / kasarékhakèn hin Dhusun Butuh // sepeninggal Harya Balabar: lalu digantikan oleh Pangeran Sujanapura / Bupati Japan [Majakerta] rumah kabupaten kemudian pindah ke Dusun Prunggahan Pangeran Sujanapura menjadi bupati lamanya 10 tahun lalu mangkat / disemayamkan di Dusun Ḅutuh//

Pada masa pemerintahan Pangeran Sujanapura, ia memindahkan pusat Kadipaten ke Dusun Prunggahan. Dalam hal itu Pangeran Sujanapura mengembalikan pusat pemerintahan ke wilayah asal, yakni wilayah Papringan (Prunggahan) yang 
digunakan oleh Adipati pertama Tuban, Raden Harya Dandang. Namun apakah bekas Kadipaten yang lama digunakan kembali oleh Pangeran Sujanapura, mengenai hal itu penulis belum mengetahui secara pasti. Perlu kajian lebih lanjut untuk menelisik hal tersebut, yang pasti Serat Babad Thuban menginformasikan Prunggahan digunakan lagi menjadi pusat Kadipaten pada masa Pangeran Sujanapura. Pangeran Sujanapura menjadi Adipati Tuban selama sepuluh tahun dan dimakamkan di Dusun Butuh. Makam dari Pangeran Sujana saat ini masuk di Desa Boto Kecamatan Semanding.

Pusat pemerintahan di Prunggahan ini juga dilanjut oleh para penerus jabatannya. Terdapat enam adipati penerusnya juga memakai Prunggahan menjadi pusat pemerintahannya. Jika dijumlah semuanya, Prunggahan digunakan menjadi pusat Kadipaten lagi selama 117 tahun. Adipati-adipati tersebutadalah Pangeran Yudanaghara, Raden Harya Surahadiningrat, Raden Harya Diphasana, Kyahi Tumenggung Cakranagara, Kyahi Phurwanegara atau dikenal dengan Tumenggung Perlos dan Kyahi Hadiphati Linder Surahadinaghara.

Kyahi Hadiphati Linder Surahadinaghara merupakan adipati terakhir yang bertempat di Prunggahan. Setelah ia meninggal dunia, jabatannya diteruskan oleh anaknya yang bernama Raden Tumenggung Surya Hadiwijaya. Raden Tumenggung Surya Hadiwijaya memindahkan pusat Kadipaten Tuban di Kampung Gowah:

28: ॥ sasédannipūn Kyahi Hadipati Lidděr

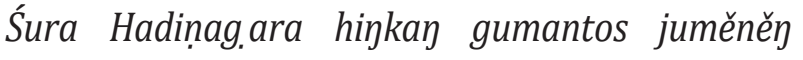
bupati pūtŕa-nnipun kakuy wasta Radén Șurya Hadiwijaya [Radén Tuměyg.un Śurya Hadiwijaya] hansal 12 tahun lajěj léréh / dalm kabupatén

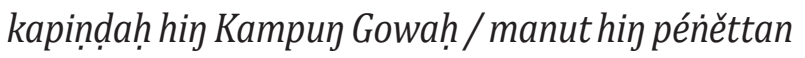
rampunnin pandaměllipun da!m kabupatén nalika tangal 1 Juli 1814//

sepeninggal Kyahi Hadipati Lidder Surahadinagara yang menggantikan menjadi bupati (yaitu) putra lelakinya (yang) bernama Raden Surya Hadiwijaya [Raden Tumenggung Surya Hadiwijaya] memerintah selama 12 tahun lalu berhenti (dari jabatan bupati) / rumah kabupaten dipindah ke Kampung Gowah / menurut catatan rumah kabupaten selesai dibangun ketika tanggal 1 Juli 1814 //

Soeparmo (1983) berpendapat bahwa Kampung Gowah yang menjadi pusat pemerintahan Raden Surya Hadiwijaya saat ini masuk di Kelurahan Sendangharjo, Kecamatan Tuban. Jika hal itu benar demikian, maka pusat pemerintahan tersebut masih digunakan hingga sekarang. Karena pendapa atau tempat tinggal Bupati Kabupaten Tuban saat ini berada di Kelurahan Sendangharjo. Pendopo ini mulai digunakan pada tanggal 1 Juli 1814 yang dibangun pada masa Raden Tumenggung Surya Hadiwijaya, dan diberi nama Kridho Manunggal.

\section{Kesimpulan}

Berdasarkan kajian di atas, dapat diketahui bahwa Tuban telah mengalami beberapa kali perpindahan pusat pemerintahan. Kadipaten Tuban mengalami tujuh kali pindah pusat Kadipaten yang pertama kali berada di Papringan, sebelah barat Gua Gabar, Kampung Sidamukti, Kampung Dagan, Kampung Kahibon, Dusun Prunggahan dan Kampung Gowah.

Jika dilihat dari administrasi saat ini,

1. Papringan sekarang masuk di Desa Prunggahan Kulon, Kecamatan Semanding;

2. Sebelah barat Gua Gabar sekarang masuk di Kelurahan Karang, Kecamatan Semanding;

3. Kampung Sidamukti sekarang masuk di Kelurahan Doromukti, Kecamatan Tuban;

4. Kampung Dagan sekarang masuk di Kelurahan Kutorejo, Kecamatan Tuban;

5. Kampung Kahibon sekarang masuk di Kelurahan Kebonsari, Kecamatan Tuban; 
6. Dusun Prunggahan sekarang masuk di Desa 7. Kampung Gowah sekarang masuk di Kelurahan Prunggahan Kulon, Kecamatan Semanding; Sendangharjo, Kecamatan Tuban.

\section{Daftar Pustaka}

Darmadi, H. (2011). Metode Penelitian Pendidikan. Bandung: Alfabeta.

de Graaf, H. J. (2001). Kerajaan Islam Pertama: Tinjauan Sejarah Politik Abad XV dan XVI. Jakarta: Pustaka Utama Grafiti.

de Graaf, H. J. (2002). Puncak Kekuasaan Mataram: Politik Ekspansi Sultan Agung. Jakarta: Pustaka Utama Grafiti.

Himmah, S. M. (2020). Islam dalam Sejarah di Kabupaten Tuban (UIN Sunan Ampel Surabaya). Retrieved from http://digilib.uinsby.ac.id/44404/

Husain, S. B., Basundoro, P., Kusuma, G., Rosyid, I., Perkasa, A., Muryadi, M., ... Pratama, A. R. (2017). Sejarah Lamongan dari Masa ke Masa. Surabaya: Airlangga University Press.

Nurhayati, F. R. (2017). Invasi Sultan Agung Mataram Terhadap Kadipaten Tuban Tahun 1619 M (UIN Sunan Ampel Surabaya). Retrieved from http://digilib.uinsby.ac.id/18416/

Patria, R. R. A. (2014). Serat Babad Tuban Suntingan Teks dan Terjemahan (Universitas Gadjah Mada). Retrieved from http://etd.repository.ugm.ac.id/penelitian/detail/74018

Prihatmoko, H. (2011). Pengelolaan Transportasi Air Pada Abad XSampai XV Masehi diJawa Timur (Universitas Indonesia). Retrieved from https://library.ui.ac.id/detail?id=20237381\&lokasi=lokal

Putra, I. E. (2019). Surutnya Eksistensi Pelabuhan Tuban dan Dampaknya Terhadap Islamisasi di Pesisir Pantai Utara Tuban Pada Abad Ke- XVII (UIN Sunan Ampel Surabaya). Retrieved from http://digilib. uinsby.ac.id/32707/

Ricklefs, M. C. (2011). Sejarah Indonesia Modern (D. Hardjowidjono, Ed.). Yogyakarta: Gadjah Mada University Press.

Sedyawati, E., Manus, M. P. B., \& Rahardjo, S. (1997). Tuban: Kota Pelabuhan Di Jalan Sutra. Retrieved from http://repositori.kemdikbud.go.id/13512/

Soeparmo, R. (1983). Catatan Sejarah 700 Tahun Tuban. Tuban: Pemerintah Kabupaten Tuban.

Susanti, N. (2010). Airlangga: Biografi Raja Pembaru Jawa Abad XI. Depok: Komunitas Bambu. . Jakarta: Komunitas Bambu.

Swie, B. T. K. (1936). Serat Babad Thuban. Kediri: Boekhandel Tan Khoen Swie.

Tim Penyusun. (1987). Menelusuri Hari Jadi Kota Tuban. Tuban: Pemerintah Kabupaten Tuban.

Tim Penyusun. (2015). Tuban Bumi Wali: The Spirit of Harmony. Tuban: Pemerintah Kabupaten Tuban.

Zed, M. (2014). Metode Penelitian Kepustakaan. Jakarta: Yayasan Pustaka Obor Indonesia.

1 Sebagai perspektif bandingan dalam melihat konstruksi sejarah Tuban sila membaca Sejarah Lamongan dari Masa ke Masa (Husain et al., 2017), di mana dalam teks tersebut Tuban merupakan sebuah wilayah yang memiliki peran unggul dari masa ke masa. 